Research article

\title{
Methylation status of ACCase promoter affects seed vigor-viability trait in Oryza sativa $\mathbf{L}$.
}

\author{
Subhabrata Ghosh and Swati Sen-Mandi* \\ Division of Plant Biology, Bose Institute, Kolkata-700009, West Bengal, India \\ *Corresponding Author: senmandi.swati@gmail.com \\ [Accepted: 17 January 2018]
}

\begin{abstract}
Rice (Oryza sativa L.) varieties exhibiting phenotypic features of high/low seed vigorviability were used to explore genetic controls associated with a varietal difference in seed vigor and viability traits. Since germination rate i.e. vigor is a reflection of the onset of metabolic activity of a hitherto quiescent embryo and seed viability reflects cell molecular events controlling macromolecular damage/protection in post-harvest (dry) quiescent embryo, expression of a housekeeping gene viz. Acetyl CoA Carboxylase (ACCase), that through its dual role controls lipid biosynthesis for germination and flavonoid biosynthesis for macromolecular protection during post-harvest aging, was studied. Our data revealed variation in ACCase gene expression among high and low vigor-viability varieties although Southern blot analysis demonstrated single copy of this gene in all the varieties regardless of their vigor-viability status. Methylation Sensitive Restriction Enzyme assay revealed methylation in $\mathrm{CpG}$ island of ACCase promoter in the phenotypically designated low vigor-viability varieties confirming that low seed vigor in rice varieties is due to low expression of ACCase gene brought about by its promoter methylation. Since promoter methylation is transferable through breeding lines this study opens up an opportunity for introgressing high seed vigor-viability trait into otherwise desirable varieties.

Keywords: Oryza sativa - Seed vigor-viability - Acetyl CoA Carboxylase - Gene copy number Gene expression - Promoter methylation.
\end{abstract}

[Cite as: Ghosh S \& Sen-Mandi S (2018) Methylation status of ACCase promoter affects seed vigor-viability trait in Oryza sativa L. Tropical Plant Research 5(1): 1-7]

\section{INTRODUCTION}

Seed vigor- seed germination performance of freshly harvested seed (Maguire 1962) and viability- assessed as seed germination performance of aged seed (Bewley \& Black 1994, Sen \& Osborne 1977) are important agronomic traits that exhibit varietal difference (Hodgkin \& Hengarty 1978, Julliano et al. 1990). These traits have been shown to be interrelated through experiments on rice seed under different storage condition have demonstrated that varieties exhibiting low seed vigor at fresh harvest are poor stores exhibiting low seed viability/storability status (Chang \& Tolentino 1983). From similar seed vigor studies, Milosevic et al. (2010) have proposed that seed vigor traits could be used as indicators of seed viability. Such empirical studies indicate a commonality in gene function where seed vigor trait through storage environment related modifications appears to manifest seed viability trait. Notwithstanding till date, there is not much information on the genetic/epigenetic control that determines the variation of these traits in the orthodox seed.

Conventionally, genetic studies on seed vigor and viability have mostly focused on identifying and mapping genes associated with different facets of germination manifested at late seedling stage through identification of QTLs such as : long root length in rice (Redona \& Mackill 1996), heat stress in Brassica oleracea (Bettey \& Finch-Savage 1998), seed tolerance to artificial ageing in Arabidopsis (Benstink et al. 2000), controlled deterioration test in Arabidopsis (Tesnier et al. 2002), seedling establishment under cold and drought stress in barley (Chloupek et al. 2003), tolerance to natural ageing (NA) in Arabidopsis (Emile et al. 2004). Such reports establish a QTL characteristic of late seedling growth without commenting on early embryonic growth that constitutes sensu stricto germination elaborated by Bettey (2000) and Holdsworth et al. (2008). 
UV radiation upregulation

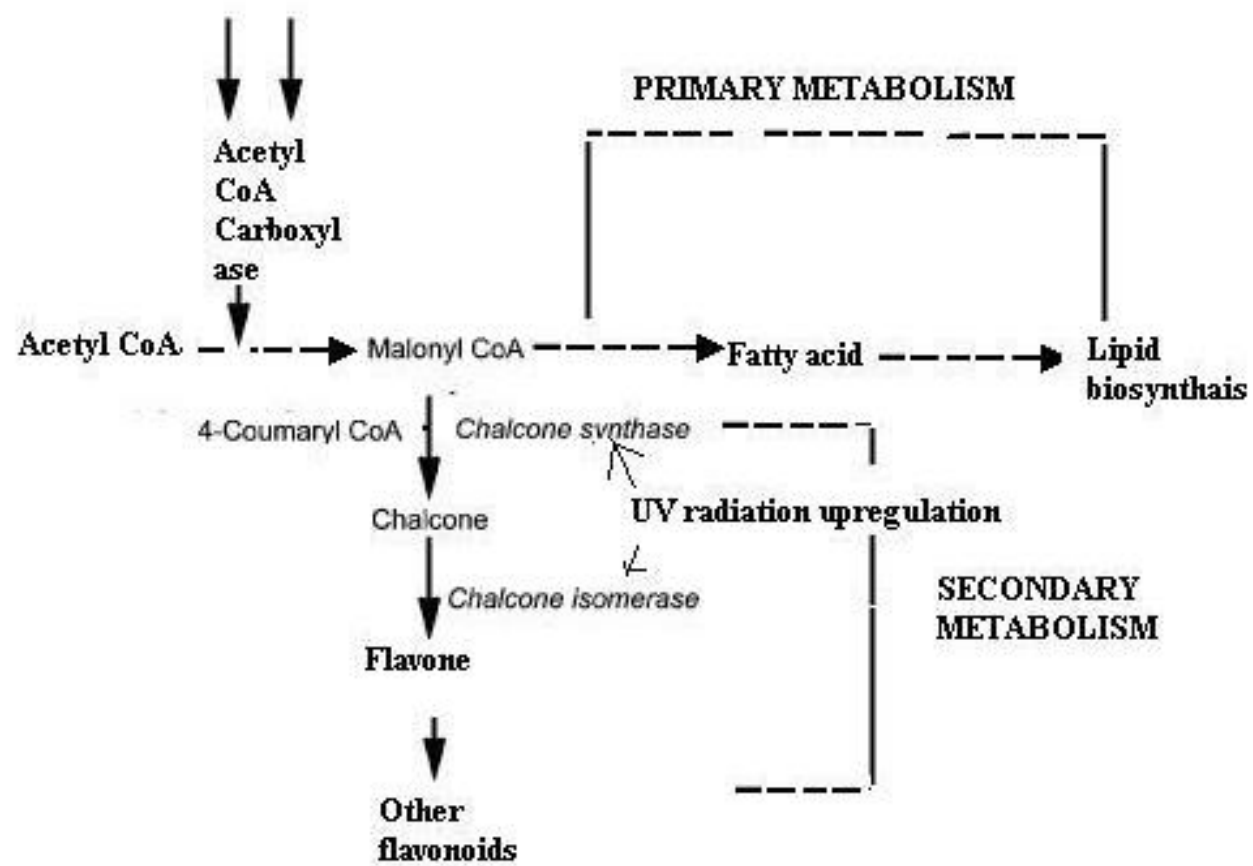

Figure 1. Interrelation between primary and secondary metabolic pathways in field grown plants.

Reports on genomics and proteomics study at sensu stricto germination include studies of Caligaris et al. (2012) who have identified a gene transcript (At3g08030) a member of the highly conserved family (DUF642) of cell wall-associated proteins in Arabidopsis that have been proposed as a marker for seed aging that determines seed viability status. Cademan et al. (2006) have studied cell molecular changes during early and late germination times of Arabidopsis using microarray for global transcript analysis plant. Weitbrecht et al. (2011) have demonstrated a massive change in Arabidopsis transcriptome during very early times of seed imbibitions i.e. when the hitherto quiescent embryo initiates growth-related cell molecular activity representing sensu stricto germination. Rajjou et al. (2004) have reported a proteomics analysis relating to accelerated Arabidopsis seed aging. Analyzing gene activity during Arabidopsis seed development Papi et al. (2000) have identified a seed-specific transcription factor viz. DAG1 in Arabidopsis. Catusse et al. (2004) have reported proteome and transcriptome profiling also in Arabidopsis for understanding the molecular mechanism underlying the seed germination and vigor trait. Subtractive cDNA approach has also been undertaken by Linkies et al. (2010) in Lepidium sativum to understand the seed germination process. While such studies have provided interesting information on seed vigor - viability (i.e. storability) these have not identified vigorviability associated major/candidate gene. Using precisely (metabolomics based) selected high and low vigor varieties of rice seed Talai \& Sen-Mandi (2010) have identified a 900bp DNA Marker associated with high vigor trait. This has been shown to be useful in germplasm screening for identification of high seed vigor-viable varieties. The authors have demonstrated a correlation (using NCBI information) of this marker with the house keeping gene ACCase that affects cellular metabolism through synthesis of lipids, necessary for cell wall synthesis in germinating embryonic axis and cellular protection in mature (dry) orthodox seed by flavonoids synthesized during seed maturation on field grown soybean plants (Mazza et al. 2000). Shyam-Choudhury \& Sen-Mandi (2012) have reported higher flavonoid content in mature high vigor seeds of rice. These reports together with reports of Baudry et al. (2004), working on Arabidopsis, indicate a possibility for ACCase enzyme as being a common controlling factor for seed vigor and viability traits. Diversion from primary metabolism to the secondary metabolic pathway (Logemann et al. 2000) through Malonyl CoA via the Phenyl Propanoid pathway for production of flavonoids occurs under natural UV radiation (Fig. 1). Mazza et al. (2000) have reported biosynthesis of flavonoids sunscreens in field grown (maturing) soybean crops. Flavonoids thus synthesized in field grown plants, remaining stored through post-harvest dry storage, confer environmental protection (Shyam-Choudhury \& Sen-Mandi 2012). Being non-enzymatic, flavonoids serve for protection against spontaneous UV radiation, a major factor causing cell molecular damage and thus loss of vigor viability 
in dehydrated cells (that are incapable of enzymatic repair) of mature seed during storage. Li et al. (1993) have reported that flavonoid mutants of Arabidopsis are hypersensitive to UV-B radiation. Flavonoids by virtue of structure-function relationship are capable of serving as antioxidants as well as sun (ultraviolet) screen (Cockell \& Knowland 1999, Kirsch 2001, Amic et al. 2003) in dry stored seeds (Bailly 2004, Christova-Bagdassarian et al. 2013). It is pertinent to mention here that most of the enzymes in this secondary metabolic pathway are upregulated by UV (Kliebenstein et al. 2002). Using enzyme kinetics studies Sen-Mandi et al. (2004) have demonstrated lower affinity of ACCase enzyme (per unit $\mu$ g protein) towards its substrate in low storable/low seed vigor-viability varieties than in the high storable/high seed vigor - viability varieties. Such findings suggest that in varieties with seed exhibiting low ACCase enzyme efficiency would manifest low seed vigor due to a) low rate of lipid metabolism at sensu stricto germination and b) low seed viability due to low level of flavonoid biosynthesis during seed maturation thereby failing to equip such low vigor seeds with flavonoids that (remaining undegraded) protect macromolecular degradation (Stapleton \& Walbot 1998) under post-harvest dry storage under spontaneous UV radiation (Shyam-Choudhury \& Sen-Mandi 2012). Depending on the extent of flavonoid synthesized the variety would remain accordingly protected and thus exhibit appropriate vigor status in the variety.

This report presents our studies on understanding the cell molecular mechanism relating to differential ACCase enzyme efficiency in high / low seed vigor-viability genotypes.

Data presented includes studies on contrasting genotypes with respect to seed vigor-viability traits.

1. ACCase gene expression in different genotypes.

2. ACCase gene copy number

3. Exploration of Methylation in the $\mathrm{CpG}$ island of the promoter region of ACCase gene in the contrasting genotypes.

\section{MATERIALS AND METHODS}

Plant Materials

Sixteen rice varieties (Oryza sativa L. var indica) viz. IET-13158 (R1), Badshabhog (R2), IET-9978 (R3), IET10890 (R4), Tulsimanjari (R5), Kataribhog (R6), Pushabasmati-1 (R7), Joya (R8), Patani-23 (R9), Jogen (R10), Lalat (R11), Pankaj (R12), Basmati Aman (R13), Kalojira(R14), Matla (R15), Mohan (R16) were used in this study. All freshly harvested seeds were stored at $4{ }^{\circ} \mathrm{C}$ over $\mathrm{CaCl}_{2}$ until used. These varieties were used after assessing their seed vigor-viability status on the basis of: a) rapid seedling growth (studied in standard germination test) b) ADH time course study on PAGE to determine transition from anaerobic to aerobic respiration coinciding with transition from sensu stricto germination to visible germination (Talai \& Sen-Mandi 2010) c) high level of DNA integrity (assayed on denaturing agarose gel) d) membrane integrity (determined by extent of lipid peroxidation) (Sen-Mandi \& Bhattacharya 2003) e) high levels of non enzymatic anti-oxidant viz. flavonoids content (Shyam-Choudhury \& Sen-Mandi 2012).

\section{Genomic DNA Extraction}

Total Genomic DNA was extracted from 3 day old young seedlings using Walbot (1988) method.

\section{Southern blotting}

Rice genomic DNA $(10 \mu \mathrm{g})$ was digested with HindIII and digested DNA was separated by electrophoresis on a $0.8 \%$ agarose gel and then blotted on to a Hybond- $\mathrm{N}^{+}$nylon membrane filter (Amersham). The filter was hybridized to $32^{\mathrm{P}}$-labeled partial ACCase cDNA probe under normal hybridization and washing conditions as described by Sambrook et al. (1989).

\section{Gene expression study by Quantitative Real Time PCR}

a. RNA extraction: Embryos extracted from $72 \mathrm{hrs}$ imbibed seeds were powdered in liquid nitrogen. The total RNA was extracted using TRIzol reagent. The yield and quality of total RNA were measured by absorbance at 230, 260, and $280 \mathrm{~nm}$ (A260/230 and A260/280 ratios) and by running samples on a 1.5\% non-denaturing agarose gel electrophoresis.

b. Conversion of mRNA to cDNA: The mRNA fraction of total RNA population was converted to cDNA using random hexamer primer and Universal RiboClone cDNA Synthesis System (Promega, USA) following manufacturer's instructions. After conversion cDNA was stored in $-20^{\circ} \mathrm{C}$.

c. Real Time PCR: In order to investigate the expression pattern of ACCase gene in contrasting varieties of rice 
seed, quantitative RT-PCR was carried out in a 96-well optical plate using a Bio-Rad iQ5 instrument and universal cycling conditions $\left(3 \mathrm{~min}\right.$ at $95^{\circ} \mathrm{C}, 40$ cycles of $10 \mathrm{~s}$ at $95^{\circ} \mathrm{C}$ and $30 \mathrm{~s}$ at $62^{\circ} \mathrm{C}$ ). A melting curve was generated at the end of each run to check the specificity of amplification. Primer efficiencies and standard deviations were calculated based on a standard curve generated. First strand cDNA were used as templates in RT-PCR reaction with two primers specific (ACCase-F 5'ACTTCTATTTCCGCGTCACC3' and ACCase-R5'TCACCCTCGTCTTCTCACAG3') to the coding sequence of ACCase cDNA. The house-keeping gene used in this reaction was UBQ5 gene which acts as an internal control. Specific primers (UBQ5-F 5'ATGATAACTCGACGGATCGC 3' and UBQ5-R 5'CTTGGATGTGGTAGCCGTTT 3') were designed according to the conserved regions of plant UBQ5 gene. The Real Time PCR amplification was performed in triplicate for target and house keeping gene for each sample.

\section{Methylation test}

Rice genomic DNA $(10 \mu \mathrm{g})$ was digested with two Methylation Sensitive Restriction Enzymes viz. NauI and MbuBI simultaneously. After double digestion PCR analysis was carried out using two primers (MetF- 5' AGgAAGGAAGCTGTGTGCTG 3' and MetR-5' CAGGGAGgAGGAGGAAGAAG 3') which have complementarity to the flanking regions of the restriction sites of the two enzymes said above. The PCR cycle was run at $94^{\circ} \mathrm{C}$ for $2 \mathrm{~min}, 35$ cycles of $94^{\circ} \mathrm{C}$ for $30 \mathrm{~s}, 55^{\circ} \mathrm{C}$ for $30 \mathrm{~s}$, and $72^{\circ} \mathrm{C}$ for 1 min followed by $72^{\circ} \mathrm{C}$ for 10 min. Electrophoresis was carried out in $1.5 \%$ agarose gel in TBE buffer along with a 50bp DNA ladder (Thermo Scientific).

\section{RESULTS AND DISCUSSION}

Southern hybridization using rice ACCase gene specific probe have revealed a single band of strong hybridization signal in each lane (Fig. 2) suggesting that ACCase exits as single copy in the rice genome irrespective of contrasting vigour - viability status. Data of this experiment demonstrates the presence of a single copy of ACCase gene in all the studied sixteen rice varieties studied regardless of their seed vigour - viability status. Being a single copy in both categories (viz. high and low vigour) suggests differential gene expression in the contrasting genotypes. This is validated by Real Time PCR studies of all the genotypes studied against ubiquitin-5 gene as the reference gene (Fig. 3). Relative-quantitative Real-Time PCR using gene-specific primers revealed high (2.5-3 times) ACCase gene expression in high vigour - viability varieties (i.e. R3, R4, $\mathrm{R} 6, \mathrm{R} 7, \mathrm{R} 9, \mathrm{R} 12, \mathrm{R} 15, \mathrm{R} 16$ ) compared to the low vigour-viability varieties (i.e. $\mathrm{R} 1, \mathrm{R} 2, \mathrm{R} 5, \mathrm{R} 8, \mathrm{R} 10, \mathrm{R} 11, \mathrm{R} 13$, R14) (Fig. 3). Ubiquitin 5 gene was the housekeeping gene used for normalizing gene expression data in this gene expression study. An interesting correlation with this finding is evident from our earlier report (Sen-Mandi et al. 2004) that has presented evidence from enzyme kinetics studies demonstrating that ACCase enzyme exhibits higher substrate affinity (i.e. high enzyme efficiency) in high vigour - viability varieties compared to low vigour - viability varieties. Low ACCase gene expression would result in low rate of lipid biosynthesis and thus delayed cell wall formation contributing to slow embryo enlargement and slow rate of embryonic growth at sensu stricto germinations that is reflected as low seed vigour. High expression of ACCase gene (Fig. 3) would be responsible for higher flavonoid (non- enzymatic antioxidants) level in high vigour-viability varieties for cell protection through adverse storage environment (viz. UV) in rice seeds (Shyam-Choudhury \& Sen-Mandi 2012).

\section{$\begin{array}{lllllllllllllllllllllllll}\text { R1 } & \text { R2 } & \text { R3 } & \text { R4 } & \text { R5 } & \text { R6 } & \text { R7 } & \text { R8 } & \text { R9 } & \text { R10 } & \text { R11 } & \text { R12 } & \text { R13 } & \text { R14 } & \text { R15 } & \text { R16 }\end{array}$}

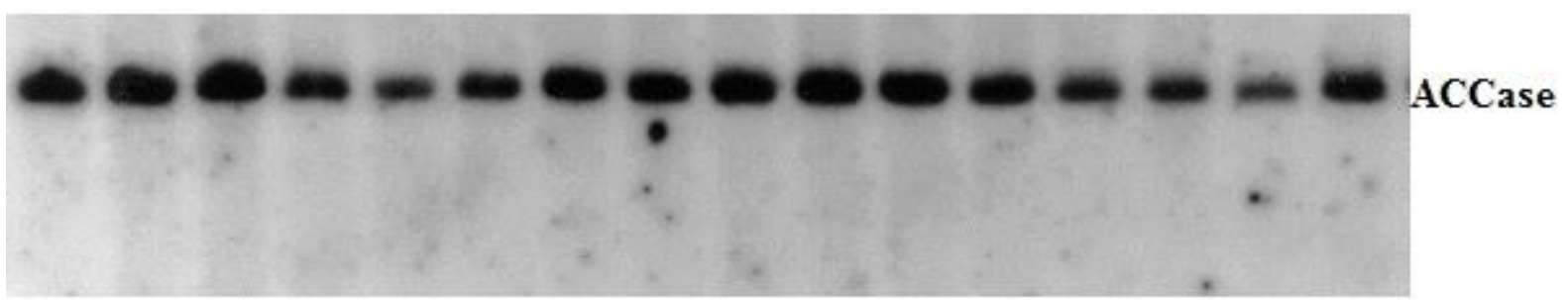

Figure 2. Southern Blot analysis showing single copy of ACCase gene in all the studied Oryza sativa varieties irrespective of their vigour-viability status (R1- R16).

Considering the experimental data of figure 2 and figure 3 in perspective, a possible epigenetic mechanism for controlling vigour-viability status in contrasting genotypes may be envisaged. Our studies on varietal difference in vigour viability status of rice seeds indicate promoter methylation as the mechanism responsible for these contrasting traits (Fig. 4). Analyzing the methylation status of the promoter region of ACCase gene using designed primers, complementary to the flanking region of the recognition sites of the two above said www.tropicalplantresearch.com 


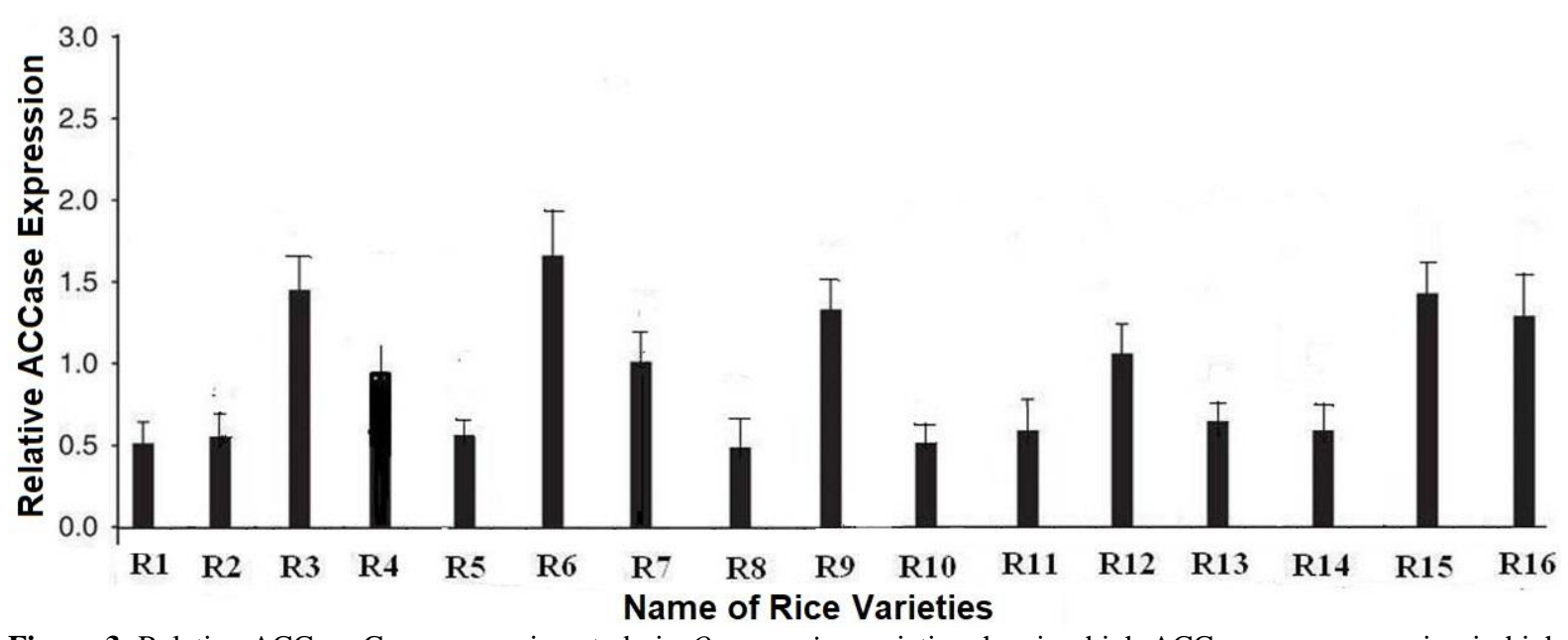

Figure 3. Relative ACCase Gene expression study in Oryza sativa varieties showing high ACCase gene expression in high vigour-viable varieties (R3, R4, R6, R7, R9, R12, R15, R16) and low gene expression in low vigour-viable varieties (R1, R2, R5, R8, R10, R11, R14, R15).

restriction enzymes (located within the $\mathrm{CpG}$ island of the promoter region of ACCase gene), revealed a visible 250 bp band (Fig. 4) in all low vigour - viability varieties (i.e. R1, R2, R5, R8, R10, R11, R13, R14) whereas no band is present in high vigour - viability varieties (i.e. R3, R4, R6, R7, R9, R12, R15, R16). Presence of a PCR product in low vigour varieties and its absence (presumably due to lack of methylation at the restriction sites of the two used restriction enzymes (viz. NaeI and MbuBI) in high vigour varieties establishes the occurrence of methylation at the promoter region in low vigour varieties. Using specific primer pairs complementary to the flanking region of the restriction sites of two above said enzymes, located within the CpG island of ACCase promoter region, a PCR derived DNA band of 250 bp was observed in the low vigour varieties; the band was absent in the high vigour varieties (Fig. 4). DNA methylation at the CpG island of the promoter region of the ACCase gene would cause low transcription efficiency and therefore low ACCase enzyme activity - an epigenetic effect, evident in low vigour varieties. The fact that vigour viability status in different varieties are found to remain unaltered through generations suggest that such epigenetic effects have been imprinted in the respective genomes.

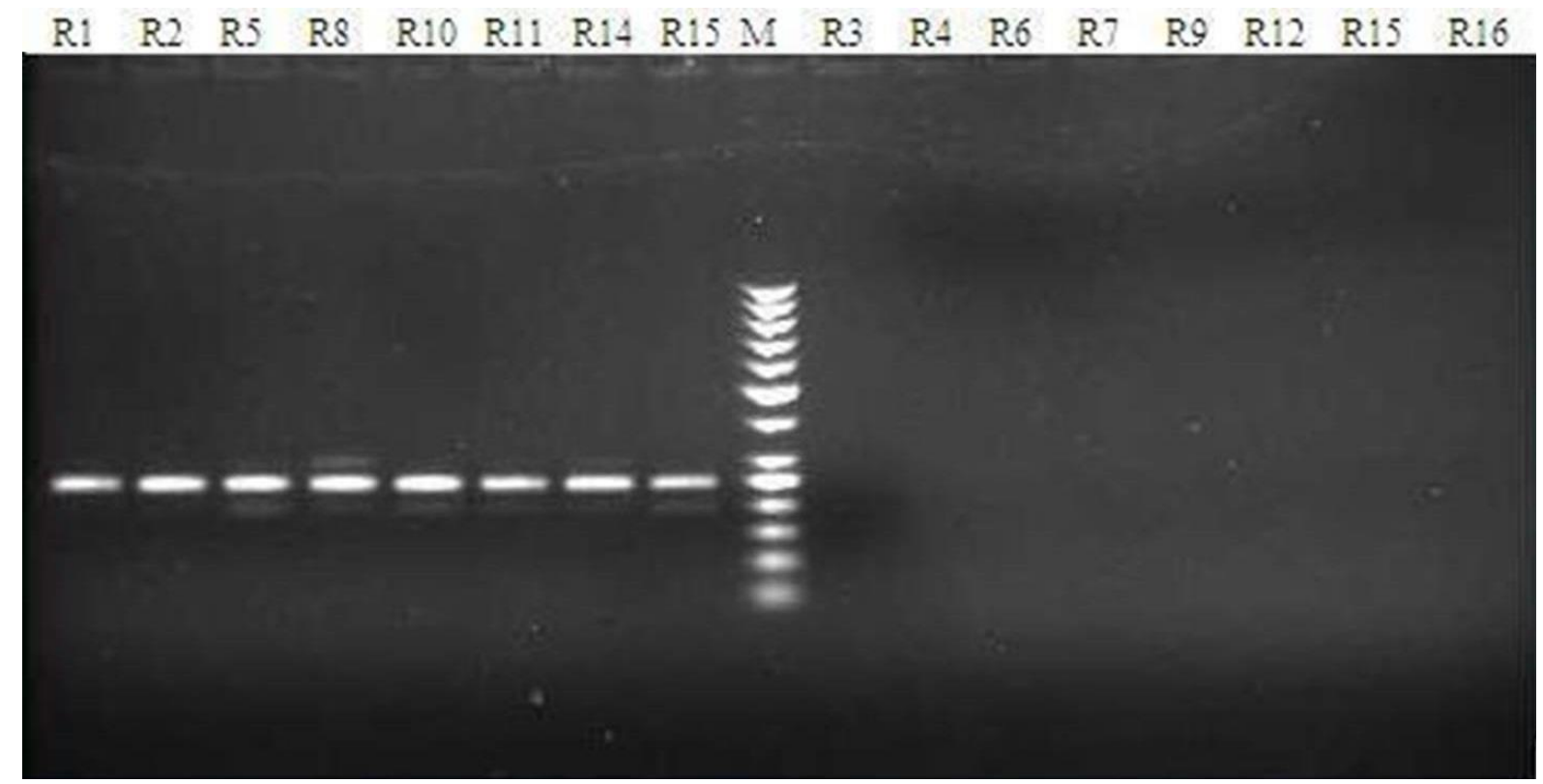

Figure 4. ACCase promoter methylation study showing a 250 bp band in low vigour-viable varieties (R1, R2, R5, R8, R10, $\mathrm{R} 11, \mathrm{R} 14, \mathrm{R} 15)$ whereas complete absence of that band in high vigour-viable varieties (R3, R4, R6, R7, R9, R12, R15, R16). M- 50bp ladder.

Studies on precisely selected (vide 'material') rice varieties demonstrated that variation in ACCase gene expression causes variation in seed vigour-viability trait despite the fact that ACCase gene copy number is "one" in all the varieties studied. The variation in ACCase gene expression among these varieties has been www.tropicalplantresearch.com 
found to be due to differential methylation status at the ACCase promoter region demonstrating that promoter methylation of ACCase gene (the critical gene regulating both vigour - through lipid biosynthesis as well as viability - through flavonoid biosynthesis) affects vigour-viability traits in freshly harvested rice seeds.

\section{ACKNOWLEDGEMENTS}

Prof. Swati Sen Mandi and Dr. Subhabrata Ghosh are grateful to Indian Council of Medical Research (ICMR) for receiving Emeritusship and Research Associateship respectively [Grant No: 74/3/2011 -Pers (EMS)]. The authors wish to acknowledge Prof. Jitendra. P. Khurana, South Campus, University of Delhi for his advice on technical details on Real Time PCR study.

\section{REFERENCES}

Amic D, Davidovic-Amic D, Beslo D \& Trinajstic N (2003) Structure-radical Scavenging activity Relationships of flavonoids. Croatica Chemica Acta 76(1): 55-61.

Bailly C (2004) Active oxygen species and antioxidants in seed biology. Seed Science Research 14: $93-107$.

Baudry A, Pourcel L, Debeaujon I, Routaboul JM, Nesi N, Caboche M \& Lepinec L (2004) Abstract of $3^{\text {rd }}$ Plant European Genomics Meeting P-064, $22^{\text {nd }}-25^{\text {th }}$ September, Lyon, France.

Benstink L, Alonso-Blanco C, Verugdenhil D, Tesnier K, Groot SPC \& Koornnef M (2000) Genetic analysis of seed-soluble oligosachharides in relation to seed storability of Arabidopsis. Plant Physiology 124: 15951604.

Bettey M \& Finch-Savage WE (1998) Stress protein content in mature Brassica seeds and their germination performance. Seed Science Research 8: 335-347.

Bettey M, Finch-Savage WE, King GJ \& Lyan JR (2000) Quantitative genetic analysis of seed vigor and pre emergence seedling growth traits in Brassica oleracea. New Phylol 148: 277-286.

Bewley JD \& Black M (1994) Seeds physiology of development and germination, $2^{\text {nd }}$ edition. Plenum Press, New York.

Cademan CSC, Toorop PE, Hilhorst HWM \& Finch-Savage WE (2006) Gene expression profiles of Arabidopsis Cvi seeds during dormancy cycling indicate a common underlying dormancy control mechanism. The Plant Journal 46: 805-822.

Caligaris LEG, Odette A, Sandra AV \& Lopez A (2012) At3g08030 transcript: a molecular marker of seed ageing. Annals of Botany 110(6): 1253-1260.

Catusse J, Rajjou L, Miche L, Lovigny Y, Robin C, Leydier E, Job C \& Job D (2004) Proteome and Transcriptome profiling to understand Seed germination and identify intrinsic markers determining seed quality, germination efficiency and early seedling vigor. In: Abstract of $3^{\text {rd }}$ Plant European genomics meeting P-106, $22^{\text {nd }}-25^{\text {th }}$ September, Lyon, France.

Chang TT \& Tolentino VT (1983) Seed longevity of three rice cultivars in three packing materials under six storage conditions. In: Agronomy Abstract, American Society of Agronomy, Madison, pp. 118.

Chloupek O, Hrstkova P \& Jurecka D (2003) Tolerance of barley seed germination to cold and drought -stress expressed as seed vigor. Plant Breeding 122(3): 199-203.

Christova-Bagdassarian VL, Bagdassarian KS \& Atanassova KS (2013) Phenolic Compounds and Antioxidant Capacity in Bulgarian Plans (dry seeds). International Journal of Advanced Research 1(9): 186-197.

Cockell CS \& Knowland J (1999) Ultraviolet radiation screening compounds. Biological Reviews 74: 311-345.

Emile JM, Clerk X, Mohammed E, Lithy EL, Elizabeth V, Gerda JR, Hetty BDV, Steven PCG, Dick V \& Marteen K (2004) Analysis of Natural allelic variation of Arabidopsis seed germination and seed longevity traits hot water using a New Recombinant inbred line populqtion. Plant Physiology 135: 432-443.

Hodgkin T \& Hegarty TW (1978) Genetically determined variation in seed germination and field emergence of Brassica oleracia. Annals of Applied Biology 88: 407-413.

Holdsworth MJ, Finch-Savage WE, Grappin P \& Job D (2008) Post-genomics dissection of seed dormancy and germination. Trends in Plant Science 13(1): 1-7.

Julliano BO, Consuelo M, \& Perez TT (1990) Varietal differences in longevity of tropical rough rice stored under ambient conditions. Seed Science and Technology 18: 45-56.

Kirsch JD (2001) Flavonoids: The good, the bad and the ugly. Free Radical Biology \& Medicine 77: 222.

Kliebenstein DJ, Lim JE, Landry LG \& Robert L (2002) Arabidopsis UVR8 regulates Ultraviolet-B signal transduction and tolerance and contains sequence similarity to human Regulator of Chromatin Condensation 
I. Plant Physiology 130(1): 234-243.

Li J, Ou-Lee TM, Raba R, Amundson RG \& Last RL (1993) Arabidopsis flavonoid mutants are hypersensitive to UV-B irradiation. Plant Cell 5: 171-179.

Linkies A, Schuster-Sherpa U, Tintelnot S, Leubner-Metzger G \& Muller K (2010) Peroxidases identified in a subtractive cDNA library approach show tissue-specific transcript abundance and enzyme activity during seed germination of Lepidium sativum. Journal of Experimental Botany 61(2): 491-502.

Logemann E, Tavernaro A, Schulz W, Somssich IE \& Hahlbrock K (2000) UV light selectively induces supply pathways from primary metabolism and flavonoid secondary product formation in parsley. Proceedings of National Academy of Sciences 97: 1903-1907.

Maguire JD (1962) Speed of Germination: Aid in Selection and Evaluation for Seedling Emergence and Vigor. Crop Science 2: 176-177.

Mazza CA, Boccalandro HE, Giordano CV, Battista D, Scopel AL \& Ballare CL (2000). Functional significance and induction by solar radiation of ultraviolet-absorbing sunscreens in field-grown soyabean crops. Plant Physiology 122: 117-126.

Milosevic M, Vujakovic M \& Karagic D (2010) Vigor tests as indicators of seed viability. Genetika 42(1): 103118.

Papi M, Sabatini S, Bouchez D, Camilleri C, Costantino P \& Vittorioso P (2000) Identification and disruption of an Arabidopsis zinc finger gene controlling seed germination. Genes \& Development 14: 28-33.

Rajjou L, Gallardo K, Debeaujon I, Vandekerckhove J, Job C \& Job D (2004) The effect of a-amanitin on the Arabidopsis seed proteome highlights the distinct roles of stored and neosynthesized mRNAs during germination. Plant Physiology 134: 1598-1613.

Redona ED \& Mckill DJ (1996) Genetic variation for seedling vigor traits in rice. Crop Science 36: $285-290$.

Sambrook J, Fritsch EF \& Maniatis T (1989) Molecular cloning: a laboratory manual. Cold Spring Harbor Laboratory Press, New York

Sen S \& Osborne DJ (1977) Decline in ribonucleic acid and protein synthesis with loss of viability during early hours of imbibition of rye (Secale cereale) embryos. Biochemical Journal 166: 33-38.

Sen-Mandi S \& Bhattacharya S (2003) Varietal difference in cellular damage associated with ageing in dry stored seeds. Indian Journal of Plant Physiology (special issue): 210-216.

Sen-Mandi S, Bhattacharya S \& Talai S (2004) Functional genomics of rice seed storability: a gene mediated positive effect of spontaneous UV radiation. In: Abstract of $3^{\text {rd }}$ Plant European genomics meeting P-073, $22^{\text {nd }}-25^{\text {th }}$ September, Lyon, France.

Shyam-Choudhury S \& Sen-Mandi S (2012) Natural Ultra Violet Radialtion on Field Grown Rice (Oryza sativa L.) Plants Confer Protection against Oxidative Stress in Seed during Storage under Subtropical Ambience. Environment and Pollution 1(2): 21-32.

Stapleton A \& Walbot V (1994) Flavonoids protects maize DNA from UV damage. Plant Physiology 105: 881889.

Talai S \& Sen-Mandi S (2010) Seed vigor related DNA marker in rice shows homology with Acetyl CoA carboxylase gene. Acta Physiologia Plantarum 32: 153-167.

Tesnier K, Strookman-Donkers HM, Van Piljen JG, Van der Geest AHM, Bino RJ \& Groot SPC (2002) A controlled deterioration test of Arabidopsis thaliama reveals genetic variation in seed quality. Seed Science Technology 30: 149-165.

Walbot V (1988) Preparation of DNA from single rice seedling. Rice Genetics Newsletter 5: 149-157.

Weitbrecht K, Muller K \& Leubner-Metzger G (2011) First off the mark: early seed germination. Journal of Experimental Botany 62(10): 3289-3309. 